\title{
Inhibition of Helicobacter pylori and Its Associated Urease by Two Regional Plants of San Luis Argentina
}

\author{
A.G. Salinas Ibáñez ${ }^{1}$, A.C. Arismendi Sosa ${ }^{1}$, F.F. Ferramola', J. Paredes ${ }^{2}$, \\ G. Wendel ${ }^{2}$, A.O. Maria ${ }^{2}$ and A.E. Vega ${ }^{1 *}$ \\ ${ }^{1}$ Área Microbiología, Facultad de Química, Bioquímica y Farmacia, Universidad Nacional de \\ San Luis. Ejercito de los Andes 950 Bloque I, Primer piso. CP5700, San Luis, Argentina \\ ${ }^{2}$ Área de Farmacología y Toxicología, Facultad de Química, Bioquímica y Farmacia, \\ Universidad Nacional de San Luis. Chacabuco y Pedernera. CP5700, San Luis, Argentina \\ *Corresponding author
}

\begin{tabular}{|c|c|}
\hline & A B S T R A C T \\
\hline & \multirow{5}{*}{$\begin{array}{l}\text { The search of alternative anti-Helicobacter pylori agents obtained mainly of medicinal } \\
\text { plants is a scientific area of great interest. The antimicrobial effects of Litrahea molleoides } \\
\text { and Aristolochia argentina extracts against sensible and resistant } H \text {. pylori strains, were } \\
\text { evaluated in vitro. Also, the urease inhibition activity and the effect on the ure A gene } \\
\text { expression mRNA was evaluated. The L. molleoides and A. argentinae extracts showed } \\
\text { antimicrobial activity against all strains assayed. Regardless of the extract assayed a } \\
\text { decrease of viable count of approximately } 2 \mathrm{log} \text { units on planktonic cell or established } \\
\text { biofilms in } H \text {. pylori strains respect to the control was observed (p<0.05). Also, both } \\
\text { extracts demonstrated strong urease inhibition activity on sensible } H \text {. pylori (p<0.05). In } \\
\text { all strains, the ureA gene expression was down regulation independently of extracts used. } \\
\text { The promising results of this work suggest that both } L \text {. molleoides and A. argentina, two } \\
\text { traditional medicinal plant of Cuyo region, could be used as } H \text {. pylori alternative treatment } \\
\text { that could attenuate virulence of bacterium and enable the host immune system to combat } \\
\text { infection. }\end{array}$} \\
\hline $\begin{array}{l}\text { Helicobacter pylori, } \\
\text { Inhibition urease, } \\
\text { Plants. }\end{array}$ & \\
\hline Article Info & \\
\hline $\begin{array}{l}\text { Accepted: } \\
\text { 23 July } 2017 \\
\text { Available Online: } \\
\text { 10 September } 2017\end{array}$ & \\
\hline & \\
\hline
\end{tabular}

\section{Introduction}

Helicobacter pylori is a Gram-negative bacterium that selectively colonizes the gastric mucosa of almost half the human population. H. pylori infection is considered to be a major public health issue worldwide for its implication in the etiology of gastro duodenal diseases, such as gastritis, peptic ulcers and gastric adenocarcinoma (GarzaGonzález et al., 2014). Several virulence factors, among them, the urease enzyme, contribute to the inflammation and pathologic changes observed in gastric mucosa.
The microorganism converts urea into ammonia and carbon dioxide modifying the acidic gastric environment to facilitate colonization (Kusters et al., 2006; Kenneth and McColl, 2010).

On the other hand, as with various bacteria studied to date, $H$. pylori can have an alternative lifestyle as a biofilm (Yonezawa et al., 2010). Biofilms are important in bacterial pathogenesis due to because allows at microbes survive and spread within the host. 
This natural community is characterized by cells that are embedded in a matrix of extracellular polymeric substances that they have produced, and exhibit an altered phenotype with respect to growth rate and gene transcription. Also, the biofilm matrix acts as shield, protecting bacteria from host defenses and antibiotics (Carron et al., 2006; Wong et al., 2016).

The eradication of $H$. pylori remains a primary goal for alleviating peptic ulcer disease and preventing associated gastric malignancies (Malfertheiner, 2017). Triple therapy consisting of a proton pump inhibitor and two antibiotics, usually amoxicillin (Amx), clarithromycin (Cla) or metronidazole (Mtz) has been recommended; however the emergence of antibiotic resistance complicates the treatment. Previous studies showed that in our region the prevalence of strains resistant to $\mathrm{Cla}$ and $\mathrm{Mtz}$ is high compared to other regions of the world (Vega et al., 2010).

Taking account the high $H$. pylori antibiotic resistance rates, principally in developing countries, the WHO listed H. pylori among 16 antibiotic-resistant bacteria that pose the greatest threat to human health and encourages the search for alternative treatments for these pathogens with high impact in Public Health (Dang and Graham, 2017).

Nowadays there is great interest in the search for alternative anti-H. pylori agents obtained mainly of medicinal plants used by the population for the treatment of various digestive disorders. Additionally, is needed the search for new targets of $H$. pylori inhibition mainly against those factors related to the initial step in colonization. Is well accepted that urease-negative mutant does not cause gastritis due to difficulties in colonization, therefore, specific inhibition of urease activity could be a possible strategy to eliminate the microorganism. In this sense, several authors have studied the inhibitory effect of plant extracts on urease activity (Amin et al., 2013; Sahin, 2015, Sarkar et al., 2016; Zhou et al., 2016).

Lithraea molleoides (Vell.) Engl. (Anacardiaceae), is a tree which grows in South America and is known in Argentina as "molle blanco". For its medicinal properties is used for the treatment of respiratory and digestive diseases among others. It is also, an ingredient of some foods such as "arrope" and "aloja" (Garro et al., 2015).

Aristolochia argentina (Aristolochiaceae), popularly known as "charrúa", is used in folk medicine for gastrointestinal disorders in the region of Cuyo, Argentina.

The aim of this study was to evaluate the antiH. pylori and urease inhibition activities of extracts obtained from two plants used as folk medicinal in San Luis, Argentina.

\section{Materials and Methods}

\section{Plant material}

L. molleoides (Vell.) Engl. (Anacardiaceae) and $A$. argentina (Aristolochiaceae) were collected in San Luis, Argentina. The plants were identified by Dr. Luis A. Del Vitto and a voucher specimen has been deposited at the Herbarium of the Universidad Nacional de San Luis, voucher $\mathrm{N}^{\circ} 515$ and $\mathrm{N}^{\circ} 9258$ respectively.

\section{Preparation of aqueous extracts}

The infusion was obtained of the air-dried plant material of each species adding boiling distilled water to powder material $(100 \mathrm{ml}: 5$ g) and left to stand at room temperature for ten minutes, according to Argentinean 
Pharmacopoeia Argentina (2007). The residual plant material was separated by filtration and the supernatant was lyophilized in a RIFICOR ${ }^{\circledR}$ freeze dryer. The crude extracts were dissolved in double distilled water (MilliQ, Millipore), and sterilized with a 0.2 -mm filter (Sartorius).

\section{Strains and culture conditions}

H. pylori NCTC 11638 (reference strain), a kind gift from Dr. Manuel López-Brea, Microbiology Service of Hospital Universitario de la Princesa, Madrid, Spain and five clinical isolates obtained from gastric antral biopsy specimens were used for this study. H. pylori strains were grown in Mueller-Hinton agar (MHA) supplemented with 7\% horse blood (MHA-HB) and identified by microscopy, urease, catalase and oxidase tests.

\section{Antibacterial activity of $L$. molleoides and A. argentina}

The antibacterial activity of both plants extract against $H$. pylori strains was assayed by broth microdilution method using Mueller Hinton Broth (MHB) according to CLSI guidelines (2007). The initial inoculum corresponding at 0.5 on the Mac Farland standard $\left(1 \times 10^{8}\right.$ colony forming units $(\mathrm{CFUs}) / \mathrm{mL})$ was used. Serial dilutions of Amx (Sigma-AldrichCo., StLouis, MO) were used as a control in the susceptibility test. Two fold dilutions of both extracts were performed to obtain the following final concentrations: from 500 to $4 \mu \mathrm{g} / \mathrm{mL}$ and from 125 to $0.08 \mu \mathrm{g} / \mathrm{mL}$ for Cla, Amx and Mtz. Broth microdilution methods were carried out in 96-well microtitre plates as previously described (Garro et al., 2015). Minimal inhibitory concentration (MIC) was measured by determining the smallest amount of extract or antibiotic needed to inhibit the visible growth of the microorganism.
Resistance was defined as the Cla MIC being $\geq 1 \mu \mathrm{g} / \mathrm{mL}$, Amx MIC $>0.5 \mu \mathrm{g} / \mathrm{mL}$ and Mtz MIC being $\geq 8 \mu \mathrm{g} / \mathrm{mL}$. All tests were performed in duplicate.

\section{Biofilm assays}

Biofilms of $H$. pylori strains were obtained as previously described by Vega et al., 2012. In the same assay, planktonic cell was removed at $48 \mathrm{~h}$ to i) viable cell counts, ii) optical microscopy and iii) RNA extraction. To quantify the biofilm, the coverslips were sampled at $48 \mathrm{~h}$, rinsed three times with phosphate-buffered saline (PBS) to remove planktonic cells and biofilm debris, and vortexed for $3 \mathrm{~min}$ in PBS to allow cell detachment from biofilm. Viable biofilm cell counts were plated onto MHA-HB by duplicate. CFUs were counted after incubation in a microaerobic atmosphere for three days at $37^{\circ} \mathrm{C}$. Also, RNA extraction was performed. The planktonic and biofilm morphology was observed by staining with $0.1 \%$ fuchsin for $15 \mathrm{~min}$ and visualized with an optical microscope.

\section{Effect of plants extract against $H$. pylori planktonic and biofilm}

Subinhibitory concentrations of the $L$. molleoides and A. argentina extracts, corresponding to 0.5 MIC respectively were tested against planktonic and biofilm cell. The effect on established biofilm was determined as following. The biofilm obtained as previously described was washed twice with PBS. Then, was placed in Petri dish with fresh medium containing L. molleoides or A. argentina extracts at a sub-inhibitory concentration and incubated in microaerobic atmosphere at $37^{\circ} \mathrm{C}$ for $26 \mathrm{~h}$. Following, the coverslips was removed and washed with PBS for i) viable cell counts; ii) optical microscopy and iii) RNA extraction. Same determinations were assayed with the 
plantonick cell treated with sub-inhibitory concentration of L. molleoides or A. argentina extracts.

\section{Gene expression}

Planktonic and biofilms cell coming from developed on the glass surfaces were treated with TRIzol reagent (Invitrogen) for total RNA extraction.

RNA quantification was performed by spectrophotometric measurement using a NanoDrop ND- $1000 \quad$ (NanoDrop Technologies) and each RNA sample was adjusted to give a final concentration of $2 \mathrm{ng} /$ $\mu \mathrm{l}$. The ureA, and housekeeping 16S rRNA genes were analyzed. cDNA was performed with random hexamer and $200 \mathrm{U}$ Moloney murine leukaemia virus reverse transcriptase (Invitrogen). The identification of amplified fragments of 411, and $390 \mathrm{bp}$ for ure A, and $16 \mathrm{~S}$ rRNA genes respectively, was performed with $1.8 \%$ agarose gel electrophoresis. The gels were stained with GelRed Nucleic Acid Gel Stain (Biotium Inc), visualized under UV light and photographed. The DNA fragment size was determined by comparison with molecular weight markers with a range of 50 to $1000 \mathrm{bp}$. Semi-quantification of the bands was performed with an image analyzer (ImageJ WCIF) against the constitutive gene $16 \mathrm{~S}$ rRNA. The ratio for ure A gene respect to the constitutive gene and the ratio of the expression of ureA gene for an extract respect to the control were established. Values less than 1 correspond to a decrease in expression and values greater than 1 correspond to an increase in expression.

\section{Inhibitory effect on urease activity}

The inhibitory effect of the L. molleoides and A. argentinae extracts on urease activity was measured using a modification of the method described by Malekzadeh et al., (2001). In brief, $2.850 \mu \mathrm{l}$ of urea broth, $50 \mu \mathrm{l}$ of either extract, and $100 \mu \mathrm{l}$ of $H$. pylori culture medium were added to a glass tube. The initial $H$. pylori number in the urea broth was about $1 \times 10^{8} \mathrm{CFU} / \mathrm{ml}$, and the final concentrations of the both extracts were 4,8 , 16,32 and $64 \mu \mathrm{g} / \mathrm{ml}$. Double distilled water $(50 \mu \mathrm{l})$ was added instead of either extract, as the control. The mixture was incubated in a microaerobic atmosphere at $37^{\circ} \mathrm{C}$ for $3 \mathrm{~h}$, and subsequently the absorbance of the culture at $560 \mathrm{~nm}$ was measured using a spectrophotometer. The inhibitory effect on urease activity was calculated using Eq.: Inhibitory effect of urease activity $(\%)=(1-$ Absorbance of sample) / (Absorbance of control) $\times 100$.

Statistical analysis. Statistical analysis was performed using Graph Pad Prism version 5.00 for Windows and Graph Pad in Stat version 3.00 for Windows (Graph Pad Software, San Diego, California, USA, www. graphpad.com). All data are expressed as the mean \pm S.E.M. (Standard Error of Mean). A probability of $\mathrm{p}<0.05$ was considered significant.

\section{Results and Discussion}

The treatment of $H$ pylori infection is very important to prevent the development of severe diseases such as gastric cancer and lymphoma, as well as to the resolution of peptic ulcer disease, and dyspepsia symptoms (Kavitt and Cifu, 2017). However, antimicrobial treatment does not achieve the much required success in the eradication because the resistance developed by the microorganism. A potential source for therapeutic use against $H$. pylori strains from natural sources is encouraging given the worldwide sensitivity studies performed using medicinal plant extracts (Sarkar et al., 2016).

The results for antibacterial activity (MICs values $\mu \mathrm{g} / \mathrm{mL}$ ) of plant extracts, Amx, Cla and Mtz, against the reference $H$. pylori and 
five clinical strains are showed in table 1 . The $L$. molleoides and $A$. argentinae extracts showed inhibitory activity against strains assayed. There was no difference in antibacterial effect between $L$. molleoides and $A$. argentina extracts. For all strains, except NCTC 11638 and HP796, the MIC values for $A$. argentinae extract were lower than $L$. molleoides extract with MIC ranging from 64 to $8 \mu \mathrm{g} / \mathrm{mL}$ and 125 to $8 \mu \mathrm{g} / \mathrm{mL}$ respectively. The Cla and Mtz resistant strains showed higher MIC values for any L. molleoides or A. argentinae extract. However, taking into account the activity for either of the two extract on sensible and resistant $H$. pylori strains, the results obtained are significant and could be considered for its use as natural alternative treatment. All strains were sensible to Amx.

Table 2 shows the results of the antimicrobial effect on $H$. pylori strains in both planktonic and biofilm state treated with sub-inhibitory concentration of L. molleoides or A. argentina using the viable count method. Regardless of the extract used we observed a decrease of approximately $2 \log$ units on planktonic cell or established biofilms in resistant $H$. pylori strains with respect to the control $(\mathrm{p}<0.05)$. The HP105 and HP109 sensible H. pylori strains in planktonic state treated with either extracts showed a decrease of viable cell of 3 $\log$ units $(p<0.05)$ and in biofilm state the decrease of viable cell was of $2 \log$ units (p<0.05). The resistant H. pylori strains, HP796 and HP173, showed a decrease of viable count 33 fold and 32.3 fold respectively at sub-inhibitory concentration of A. argentina $(\mathrm{p}<0.05)$. When used a subinhibitory concentration of $L$. molleoides a similar decrease of viable count, 28 and 29 folds for same strains, was observed.

The characteristic helical shape of bacterium is a prerequisite for to successfully carry out the invasion and subsequent colonization in the gastric mucosa (Wang et al., 2010). In this study, optical microscopy showed morphological changes in the presence of either L. molleoides or A. argentina extracts. Untreated cells had a helical shape, whereas the extract-treated cells had coccoid shape. The figure 1 shows the results obtained with NCTC 11638 untreated and treated with $L$. molleoides or A. argentina in both cell states. The morphology changes at coccoid shapes of H. pylori strains have been associated with to loss of culturability and reduction in the total amounts and integrity of RNA (Worku et al., 1999; Lee et al., 2016). The results obtained is according to the observed for reduction in viable counts. The ability of $H$. pylori to form biofilm it facilitates the colonization, also gives resistance to mucus turnover and gastric peristalsis. Interestingly, in this work, we demonstrate that both extracts act on the established biofilm of sensitive and resistant H. pylori strains.

Table.1 MICs of Lithraea molleoides and Aristolochia argentina extracts and antibiotic for six Strains of Helicobacter pylori

\begin{tabular}{lccccc}
\hline H. pylori & \multicolumn{5}{c}{ MIC $(\mu \mathrm{g} / \mathrm{ml})$ plants extracts and Antibiotic } \\
Strains & Cla & Mtz & Amx & L. molleoides & A. argentina \\
\hline NCTC 11638 & 0.5 & 0.25 & 0.25 & 16 & 16 \\
HP796 & 4 & 16 & 0.5 & 125 & 125 \\
HP173 & 4 & 16 & 0.5 & 125 & 64 \\
HP105 & 0.25 & 1 & 0.125 & 16 & 8 \\
HP109 & 0.5 & 2 & 0.25 & 16 & 8 \\
HP857 & 0.25 & 1 & 0.25 & 64 & 32
\end{tabular}

${ }^{a}$ Values are average derived from two determinations 
Table.2 Viable counts of Helicobacter pylori planktonic and biofilm cell treated with sub-inhibitory concentration of Lithraea molleoides or Aristolochia argentina.

\begin{tabular}{|c|c|c|c|c|c|c|}
\hline \multirow{2}{*}{$\begin{array}{l}\text { H. pylori } \\
\text { strains }\end{array}$} & \multicolumn{2}{|c|}{ State cell } & \multicolumn{2}{|c|}{ Litrahea molleoides } & \multicolumn{2}{|c|}{ Aristolochia argentina } \\
\hline & Planktonic & Biofilm & Planktonic & Biofilm & Planktonic & Biofilm \\
\hline NCTC 11638 & $2.5 \times 10^{8} \pm 1.0$ & $2.3 \times 10^{4} \pm 0.3$ & $6.5 \times 10^{6} \pm 0.1^{\mathrm{a}}$ & $1.5 \times 10^{2} \pm 0.3^{b}$ & $6.3 \times 10^{6} \pm 0.3^{c}$ & $1.3 \times 10^{2} \pm 0.6^{\mathrm{d}}$ \\
\hline HP796 & $2.5 \times 10^{9} \pm 0.1$ & $4.5 \times 10^{4} \pm 0.1$ & $8.9 \times 10^{7} \pm 0.1^{\mathrm{a}}$ & $3.4 \times 10^{2} \pm 0.1^{\mathrm{b}}$ & $7.5 \times 10^{7} \pm 0.1^{\mathrm{c}}$ & $3.6 \times 10^{2} \pm 0.3^{\mathrm{d}}$ \\
\hline HP173 & $2.1 \times 10^{9} \pm 0.3$ & $3.5 \times 10^{4} \pm 0.3$ & $7.3 \times 10^{7} \pm 0.1^{\mathrm{a}}$ & $2.9 \times 10^{2} \pm 0.3^{b}$ & $6.5 \times 10^{7} \pm 0.1^{c}$ & $3.0 \times 10^{2} \pm 0.3^{\mathrm{d}}$ \\
\hline HP105 & $1.4 \times 10^{9} \pm 0.2$ & $1.3 \times 10^{4} \pm 0.2$ & $4.1 \times 10^{6} \pm 0.3^{\mathrm{a}}$ & $1.7 \times 10^{2} \pm 0.6^{b}$ & $3.3 \times 10^{6} \pm 0.3^{c}$ & $1.5 \times 10^{2} \pm 0.6^{\mathrm{d}}$ \\
\hline HP109 & $1.5 \times 10^{9} \pm 0.3$ & $1.7 \times 10^{4} \pm 0.3$ & $5.1 \times 10^{6} \pm 0.2^{\mathrm{a}}$ & $1.3 \times 10^{2} \pm 0.3^{b}$ & $4.9 \times 10^{6} \pm 0.5^{c}$ & $1.1 \times 10^{2} \pm 0.8^{\mathrm{d}}$ \\
\hline HP857 & $3.2 \times 10^{9} \pm 0.3$ & $5.3 \times 10^{4} \pm 0.3$ & $4.3 \times 10^{7} \pm 0.3^{\mathrm{a}}$ & $2.8 \times 10^{2} \pm 0.2^{b}$ & $3.7 \times 10^{7} \pm 0.1^{\mathrm{c}}$ & $2.7 \times 10^{2} \pm 0.3^{\mathrm{d}}$ \\
\hline
\end{tabular}

Data are represented as means $\log 10 \pm$ S.D. of total cells counts of two independent experiments

(a-d) mean values with different superscripts for planktonic or biofilm state treated with L. molleoides or A. argentina are significantly different

Table.3 Inhibitory effects of extracts on the urease activity in Helicobacter pylori strains

\begin{tabular}{|c|c|c|c|c|c|c|c|c|c|c|}
\hline \multirow{3}{*}{$\begin{array}{l}\text { H. pylori } \\
\text { strains }\end{array}$} & \multicolumn{5}{|c|}{ Inhibitory effect on urease activity (\%) L.molleoides } & \multicolumn{5}{|c|}{ Inhibitory effect on urease activity (\%) A. argentina } \\
\hline & \multicolumn{5}{|c|}{ Extract concentration $(\mu \mathrm{g} / \mathrm{ml})$} & \multicolumn{5}{|c|}{ Extract concentration $(\mu \mathrm{g} / \mathrm{ml})$} \\
\hline & 4 & 8 & 16 & 32 & 64 & 4 & 8 & 16 & 32 & 64 \\
\hline HP796 & $9 \pm 0.9$ & $14 \pm 1.3$ & $16 \pm 1.5$ & $18 \pm 1.1$ & $25 \pm 1.3$ & $11 \pm 0.6$ & $19 \pm 1.3$ & $23 \pm 0.9$ & $25 \pm 1.3$ & $27 \pm 1.1$ \\
\hline HP173 & $10 \pm 1.3$ & $13 \pm 0.3$ & $15 \pm 2.3$ & $17 \pm 1.1$ & $23 \pm 2.1$ & $13 \pm 1.8$ & $17 \pm 1.5$ & $21 \pm 2.1$ & $23 \pm 1.5$ & $25 \pm 1.3$ \\
\hline HP109 & $21 \pm 0.9$ & $33 \pm 1.1$ & $35 \pm 0.7$ & $38 \pm 1.3$ & $44 \pm 0.9 *$ & $23 \pm 1.0$ & $39 \pm 1.3$ & $40 \pm 1.1$ & $42 \pm 1.1$ & $46 \pm 0.5^{*}$ \\
\hline HP857 & $19 \pm 2.3$ & $30 \pm 0.5$ & $32 \pm 1.0$ & $36 \pm 1.5$ & $41 \pm 1.3 *$ & $21 \pm 1.7$ & $37 \pm 1.1$ & $39 \pm 0.7$ & $43 \pm 1.5$ & $45 \pm 1.0 *$ \\
\hline
\end{tabular}


Table.4 Effect of extracts on the urease gene expression in Helicobacter pylori strains

\begin{tabular}{lcccc}
\hline \multirow{2}{*}{$\begin{array}{l}\text { H. pylori } \\
\text { strains }\end{array}$} & \multicolumn{2}{c}{$\begin{array}{c}\text { Effect of } L \text {. molleoides } \\
\text { /fold change }\end{array}$} & \multicolumn{2}{c}{$\begin{array}{c}\text { Effect of A. argentina } \\
\text { / fold change }\end{array}$} \\
\cline { 2 - 5 } NCTC 11638 & Planktonic & Biofilm & Planktonic & Biofilm \\
HP796 & -2.9 & -1.9 & -2.7 & -2.1 \\
HP173 & -2.1 & -1.7 & -1.9 & -1.5 \\
HP105 & -1.9 & -1.3 & -1.7 & -1.7 \\
HP109 & -3.5 & -2.1 & -3.9 & -2.3 \\
HP857 & -3.7 & -2.3 & -3.5 & -2.5 \\
\hline
\end{tabular}

Data are represented as means of two independent experiments

Fig.1 Morphological changes of NCTC 11638 Helicobacter pylori strain in the presence of Lithraea. molleoides or Aristolochia argentina extracts. A: planktonic and D: biofilm control; B: planktonic and E: biofilm treated with a sub-inhibitory concentration of L. molleoides extract; C: planktonic and F: biofilm treated with a sub-inhibitory concentration of A. argentina extract. The optical micrographs stained with $0.1 \%$ fuchsin showed conversion of the helical to coccoid form (arrow) after treated with either extracts. Results are representative of two independent experiments.

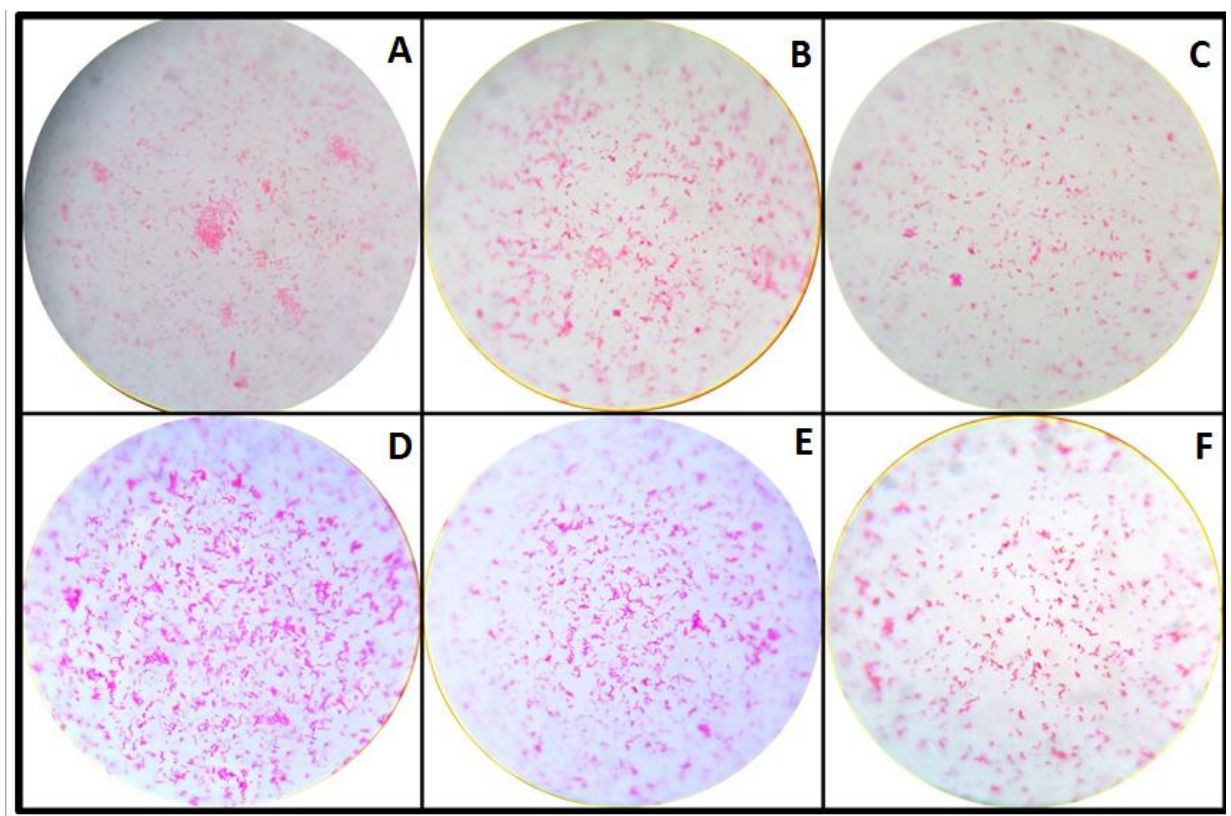

The pathogenesis of $H$. pylori is attributed to its ability to colonize the gastric epithelium and its virulence factors (Ansari and Yamahoka, 2017). The human immune system cannot eliminate because of the bacterial ability of immune evasion. Thus, neutralizing or suppressing the expression of virulence factors that allow attenuates the pathogenicity of the bacterium and facilitate the elimination for the host innate immune system is desired to overcome infection (Fernebro, 2011). In this sense, urease inhibitors had been isolated from some plants and herbs (Amin et al., 2013; Hřibová et al., 2014; Modolo et al., 2015). We studied two regional plants that have not been screened yet for its urease inhibition activities in $\mathrm{H}$. pylori strains in 
order to determine its effect on the main factor of colonization and virulence of the bacterium. Table 3 show the inhibitory effects of $L$. molleoides and $A$. argentina extracts on the urease activity in $H$. pylori strains. The $A$. argentina extract showed higher urease inhibitory activity than L. molleoides for all concentrations tested in all strains; however, no statistically significant differences were observed. Respect to sensible $H$. pylori strains, both extracts demonstrated to be strongest that on resistant $H$. pylori strains. The urease activity of sensible $H$. pylori strains decreased by more than $20 \%$ at $64 \mu \mathrm{g} / \mathrm{ml}$ concentration respect to $4 \mu \mathrm{g} / \mathrm{ml}$ of either extracts $(\mathrm{p}<0.05)$, whereas that the resistant strains decreased by about $12 \%$. Our results confirm the antibacterial activity of $L$. molleoides and A. argentina extracts against $H$. pylori strains for inhibition of urease activity. Lee et al., 2016 using the same method demonstrated the inhibition of urease of methanol and ethanol Inula britannica extracts at $10 \mathrm{mg} / \mathrm{mL}$ concentration against three reference strains $\mathrm{Mtz}$ sensible. On the other hand, on a total of 42 aqueous plants extracts using the phenol-hypochlorite method showed antiurease activity with a range of 17.8$80.0 \%$ inhibition at a concentration $0.2 \mathrm{mg} / \mathrm{mL}$ (Hřibová et al., 2014). Amin et al., 2013 in the $H$. pylori urease inhibitory assay, using methanol and acetone extracts of Acacia nilotica and Calotropis procera demonstrated significant inhibition depending to the concentration and type of the extract (Amin et al., 2013).

The presence of sublethal levels of antibiotics can alter the expression of genes related to the bacterial stress and virulence on a transcriptional level (Andersson and Hughes, 2014). In order to determine the molecular mechanism of action of both extract, the expression of the ureA gene induced by subinhibitory concentration of either extracts, was investigated by RT-PCR and semicuantified using ImageJ. Table 4 shows the effect of both extracts on expression of ureA gene mRNA. In all strains, the ureA gene expression was down regulation independently of extracts used. The sensible $H$. pylori strains showed an expression markedly reduced of ureA gene mRNA ranging 3.5 to 3.9 fold, when the strains were treated with either extracts at sub-inhibitory concentration respect to the control; however no difference statistical was observed. The ureA gene expression from cell of $H$. pylori in a biofilm established showed slightly lower down regulation compared to planktonic cells with both extracts. This suggests that $L$. molleoides and $A$. argentina extracts decrease ure $\mathrm{A}$ gene expression and agree according to the results obtained in the assay of inhibition of urease activity.

Bioactive compounds of medicinal plants possess recognized antimicrobial properties. The results obtained in this work can be linked to alkaloids, aristolochic acid and terpenes present in A. argentina among other active principles. Gutkind et al., demonstrated that $A$. argentina extract have antibacterial and antifungal activity (Gutkind et al., 1981). On the other hand, L. molleoides possess phenolic acids, mannitol, flavonoids as bioactive compounds for which we demonstrated activity against sensible and resistant $H$. pylori strains (Garro et al., 2015). Additionally, we demonstrated that L. molleoides extract confers gastroprotective properties against gastric ulcers induced by different necrotizing agents in Wistar rats (Garro et al., 2015).

The decrease of urease activity of all the $H$. pylori strains obtained in this work is of therapeutic significance because the plants extract assayed would be potent anti-H. pylori agents used alone or in combination with antibiotics. The virulence genes are important by assesses druggable targets in the search for new tools in the antibacterial arsenal. Also, could be used as a potential combinatorial approach of anti-virulence therapeutics (Schroeder et al., 2017). In this sense, the proton-pump inhibitors such as omeprazole and lansoprazole currently used in the treatment of $H$. pylori infections combined with antibiotics are potent urease inhibitors. 
The results obtained with two extract of traditional medicinal plant used in the Cuyo region, Argentina are promising because the extracts demonstrated to be very effective against $H$. pylori strains sensible and resistant and in planktonic or biofilm state. Additionally, we demonstrated the inhibitory effect on the urease activity of two extracts and first time determined a molecular mechanism by decrease of ureA gene expression mRNA. This could attenuate bacterium and enable the host immune system to combat infection.

\section{Acknowledgments}

The authors thank Patricia Gomez, Patricia Vallejos for providing the gastric biopsy specimens. The authors have no conflict of interest to declare. This work was supported by funds of Science and Technology Project 23614 from the National University of San Luis.

\section{References}

Amin, M., Anwar F., Naz F., Mehmood T., Saari N. 2013. Anti-Helicobacter pylori and urease inhibition activities of some traditional medicinal plants. Molecules 18: 2135-2149.

Andersson, D.I., Hughes D. 2014. Microbiological effects of sublethal levels of antibiotics. Nature Reviews Microbiology; doi: 10.1038/nrmicro 3270

Ansari, S., Yamaoka, Y. 2017. Survival of Helicobacter pylori in gastric acidic territory. Helicobacter. 1-13.

Carron, M.A., Tran V.R., Sugawa C., Coticchia J.M. 2006. Identification of Helicobacter pylori biofilms in human gastric mucosa. Journal of Gastrointestinal Surgery 10: 712-717.

Clinical and Laboratory Standards Institute, 2007. Methods for Antimicrobial Susceptibility testing of Anaerobic Bacteria; Approved Standard, M11-A7 \&M11-S, seventh edition. Wayne, PA, USA

Dang Bich, N., Graham David Y. 2017. Helicobacter pylori infection and antibiotic resistance: a WHO high priority? Nature reviews Gastroenterology Hepatology 14: 1-2.

Farmacopea Nacional Argentina. 1978. Comisión permanente de la Farmacopea Argentina, 6th ed. Ministerio de Salud de la Nación, Argentina.

Fernebro, J., 2011. Fighting bacterial infectionsfuture treatment options. Drug Resist Updat 14:125-139.

Garro, M.F., Salinas Ibáñez AG., Vega AE., Arismendi Sosa AC., Pelzer LE., Saad JR., María AO. 2015. Gastroprotective effects and antimicrobial activity of Lithraea molleoides and metabolites against Helicobacter pylori. 2015. Journal of Ethnopharmacology 176: 469-474.

Garza-González, E., Perez-Perez GI, Maldonado-Garza HJ, Bosques-Padilla FJ. 2014. A review of Helicobacter pylori diagnosis, treatment, and methods to detect eradication. World J Gastroenterol. 20(6): 1438-1449.

Gutkind, G., Martino V., Graña N., Coussio J., de Torres R. 1981. Screening of South American plants for biological activities. Antibacterial and antifungal activity. Fitoterapia 52: 213-218.

Hřibová, P., Khazneh E., Žemlička M., Švajdlenka E., Ghoneimb MM, Elokelyd KM., Rossbe AS. 2014. Antiurease activity of plants growing in the Czech Republic. Natural Product Research: Formerly Natural Product Letters, 28:12, 868-873

Kavitt, R.T., Cifu AS. 2017. Management of Helicobacter pylori. JAMA, 15: 15721573.

Kenneth, E.L., McColl, M.D. 2010. Helicobacter pylori Infection. N Engl J Med; 362:1597-604.

Kusters, J.G., van Vliet AHM., Kuipers EJ. 2006. Infection Pathogenesis of Helicobacter pylori. Clinical Microbiology Reviews, 19: 449-490.

Lee, Y.H., Lee NK, Paik HD. 2016. Antimicrobial Characterization of Inula britannica against Helicobacter pylori on gastric condition. J. Microbiol. Biotechnol, 26: 1011-1017. 
Malekzadeh, F., Ehsanifar H, Shahamat M, Levin M, Colwell RR. 2001. Antibacterial activity of black myrobalan (Terminalia chebulaetz) against Helicobacter pylori. Int. J. Antimicrob. Agents 18: 85-88.

Malfertheiner, P., Megraud F, O'Morain CA, Gisbert J P, Kuipers E J, Axon AT, Bazzoli F, Gasbarrini A, Atherton J, Graham DY, Hunt R, Moayyedi P, Rokkas T, Rugge M, Selgrad M, Suerbaum S, Sugano K, El-Omar, EM on behalf of the European Helicobacter and Microbiota Study Group and Consensus panel. 2017. Management of Helicobacter pylori infection the Maastricht V/Florence consensus report. Gut 66: 6-30.

Modolo, L.V., de Souza AX, Horta LP, Araujo DP., de Fátima A. 2015. An overview on the potential of natural products as ureases inhibitors: A review. Journal of Advanced Research 6: 35-44

Sahin, H., 2015. Honey as an apitherapic product: its inhibitory effect on urease and xanthine 451 oxidase. Journal of Enzyme Inhibition and Medicinal Chemistry, 31(3), 490-494.

Sarkar, A., De R., Mukhopadhyay AK. 2016. Curcumin as a potential therapeutic candidate for Helicobacter pylori associated diseases. World J Gastroenterol; 22(9): 2736-2748.

Schroeder, M., Brooks BD., Brooks AE. 2017. The Complex Relationship between Virulence and Antibiotic Resistance. Genes 2017, 8, 39;

Vega, A.E., Cortiñas, T.I., Puig, O.N., Silva, H.J. 2010. Molecular characterization and susceptibility testing of Helicobacter pylori strains isolated in western
Argentina. Int.J.Infect.Dis.14: 85-92.

Vega, AE., Persia FA., Salinas-Ibáñez GA, Alarcón T, Lucero Estrada SM.C., Cortiñas TI, Silva HJ. 2012. Helicobacter pylori Biofilm formation and gene expression on abiotic surfaces using a cyanobacterial extract. Journal of Life Sciences 6: 1317-1327.

Wang, J., Wang WH., Li J., Liu FX. 2010. Celecoxib inhibits Helicobacter pylori colonization-related factors. World $\mathbf{J}$ Gastroenterol 16: 846-853

Wong, E.H.J., Ng, C.G., Chua EG., Tay ACY, Peters F., Marshall BJ., Ho B., Goh KL., Vadivelu J., Loke MF. 2016. Comparative genomics revealed multiple Helicobacter pylori genes associated with biofilm formation in Vitro. PLoSONE 11: $1-16$

Worku, M.L., Sidebotham RL, Walker MM, Keshavarz T, Karim QN. 1999. The relationship between Helicobacter pylori motility, morphology and phase of growth: implications for gastric colonization and pathology. Microbiology 145: 2803-2811

Yonezawa, H., Osaki T., Kurata S., Zaman C., Hanawa T., Kamiya S. 2010. Assessment of in vitro biofilm formation by Helicobacter pylori $\mathrm{J}$ Gastroenterol and Hepatol 25: 90-94.

Zhou, JT., Li CL., Tan LH., Xu YF., Liu YH., Mo ZZ., Dou YX., Su R., Su ZR., Huang P., Xie JH. 2016. Inhibition of Helicobacter pylori and its associated urease by Palmatine: investigation on the potential mechanism. PLoS ONE 12(1): e0168944.

\section{How to cite this article:}

Salinas Ibáñez, A.G., A.C. Arismendi Sosa, F.F. Ferramola, J. Paredes, G. Wendel, A.O. Maria and Vega, A.E. 2017. Inhibition of Helicobacter pylori and Its Associated Urease by Two Regional Plants of San Luis Argentina. Int.J.Curr.Microbiol.App.Sci. 6(9): 2097-2106. doi: https://doi.org/10.20546/ijcmas.2017.609.258 